\title{
Profile of medication use during pregnancy: Results of the BRISA study, São Luís -
}

\section{MA, Brazil}

Perfil do uso de medicamentos durante a gestação: Resultados do estudo BRISA, São Luís - MA, Brasil

Perfil de uso de medicamentos durante el embarazo: Resultados del estudio BRISA, São Luís - MA, Brasil

\author{
Renata Monteiro Lima \\ ORCID: https://orcid.org/0000-0003-1406-4278 \\ Universidade Federal do Maranhão, Brazil \\ E-mail: remolima@yahoo.com.br \\ Joseane Lima Prado Godinho \\ ORCID: https://orcid.org/0000-0001-8057-5469 \\ Universidade Federal do Maranhão, Brazil \\ E-mail:jlpg.godinho@gmail.com, \\ Elma Izze da Silva Magalhães \\ ORCID: https://orcid.org/0000-0001-9909-9861 \\ Universidade Federal do Maranhão, Brazil \\ E-mail: elma_izze@ hotmail.com \\ Anaximandro Braga Brito \\ ORCID: https://orcid.org/0000-0001-9810-1747 \\ Universidade de São Paulo, Brazil \\ E-mail: anaximandrobraga@gmail.com \\ Maria Helena Seabra Soares de Britto \\ ORCID: https://orcid.org/0000-0001-7155-1633 \\ Universidade Federal do Maranhão, Brazil \\ E-mail: mhdebritto@gmail.com \\ Maria Teresa Seabra Soares de Britto e Alves \\ ORCID: https://orcid.org/0000-0002-4806-7752 \\ Universidade Federal do Maranhão, Brazil \\ E-mail: mtseabra@gmail.com \\ Alcione Miranda dos Santos \\ ORCID: https://orcid.org/0000-0001-9711-0182 \\ Universidade Federal do Maranhão, Brazil \\ E-mail: alcione.miranda@gmail.com
}

\begin{abstract}
Objectives: To describe the medication profile used during pregnancy in a Brazilian capital. Methods: Descriptive cross-sectional study with data from BRISA study in São Luís, Maranhão. Participants were interviewed in hospitals and maternity hospitals after delivery and were asked about the use of medications during pregnancy. The drugs were classified according the Anatomical Therapeutic Chemical Classification and risk categories of the Food and Drug Administration. Results: 5,110 puerperal women were interviewed, of which $93.5 \%$ reported the use of at least one medication during pregnancy. The most frequent medications were: antianemic preparations (ferrous sulfate: $72.2 \%$; iron and multivitamins: $4.9 \%$, folic acid: $62.9 \%$ and associations with folic acid: $6.7 \%$ ), vitamins (multivitamins and others minerals: $30.3 \%$ ), analgesics (paracetamol: 12.3\%), antibacterials for systemic use (cephalexin: 5.6\%), antiemetics and anti-nauseating agents (scopolamine butylbromide: 5.4\%) and antihypertensives (methyldopa): $3.6 \%$ ). Among the drugs reported: $74.5 \%$ were from category A, $18.9 \%$ from category B, $5.5 \%$ from category C, $1.0 \%$ from category $\mathrm{D}$ and $0.1 \%$ from category $\mathrm{X}$. Conclusions: Despite, the higher prevalence of medication use during pregnancy, most of which are considered safe in pregnancy. However, it is important that the use of drugs during pregnancy is monitored and guided by health professionals in order to ensure its rational use.
\end{abstract}

Keywords: Pharmaceutical preparations; Pregnancy; Epidemiology; Descriptive; Prevalence.

\section{Resumo}

Objetivos: Descrever o perfil do uso de medicamentos na gestação em uma capital brasileira. Métodos: Estudo transversal descritivo com dados do estudo BRISA em São Luís, Maranhão. As participantes foram entrevistadas nos 
Research, Society and Development, v. 11, n. 2, e21811224986, 2022

(CC BY 4.0) | ISSN 2525-3409 | DOI: http://dx.doi.org/10.33448/rsd-v11i2.24986

hospitais e maternidades após o parto, sendo questionadas sobre o uso de medicamentos na gestação. Os medicamentos foram classificados de acordo com a Anatomical Therapeutic Chemical Classification e categorias de risco da Food and Drug Administration. Resultados: Foram entrevistadas 5.110 puérperas, das quais 93,5\% relataram o uso de pelo menos um medicamento na gestação. Os medicamentos mais frequentes foram: preparações antianêmicas (sulfato ferroso: 72,2\%; ferro e multivitaminas: 4,9\%, ácido fólico: 62,9\% e associações com ácido fólico: 6,7\%), vitaminas (multivitamínicos e outros minerais: 30,3\%), analgésicos (paracetamol: 12,3\%), antibacterianos de uso sistêmico (cefalexina: 5,6\%), antieméticos e antinauseantes (butilbrometo de escopolamina: 5,4\%) e anti-hipertensivos (metildopa: 3,6\%). Dentre os medicamentos relatados: $74,5 \%$ foram da categoria A, 18,9\% da categoria $\mathrm{B}, 5,5 \%$ da categoria $\mathrm{C}, 1,0 \%$ da categoria D e $0,1 \%$ da categoria X. Conclusões: Observou-se elevada prevalência de utilização de medicamentos na gestação, sendo a maioria de uso considerado seguro na gravidez. Porém, é importante que a utilização de fármacos na gestação seja monitorada e orientada por profissionais de saúde visando garantir o seu uso racional.

Palavras-chave: Medicamentos; Gestação; Epidemiologia; Estudos descritivos; Prevalência.

\section{Resumen}

Objetivos: Describir el perfil de medicación utilizada durante el embarazo en una capital brasileña. Métodos: Estudio descriptivo transversal con datos del estudio BRISA en São Luís, Maranhão. Las participantes fueron entrevistadas en hospitales y maternidades después del parto y se les preguntó sobre el uso de medicamentos durante el embarazo. Los medicamentos se clasificaron de acuerdo con la Clasificación Química Anatómica Terapéutica y las categorías de riesgo de la Administración de Alimentos y Medicamentos. Resultados: Se entrevistó a 5.110 puérperas, de las cuales el 93,5\% refirió el uso de al menos un medicamento durante el embarazo. Los medicamentos más frecuentes fueron: preparados antianémicos (sulfato ferroso: 72,2\%; hierro y multivitamínicos: 4,9\%, ácido fólico: $62,9 \%$ y asociaciones con ácido fólico: 6,7\%), vitaminas (multivitamínicos y otros minerales: 30,3\%), analgésicos (paracetamol: 12,3\%), antibacterianos de uso sistémico (cefalexina: 5,6\%), antieméticos y antieméticos (butilbromuro de escopolamina: 5,4\%) y antihipertensivos (metildopa): 3,6\%). Entre los medicamentos reportados: 74,5\% eran de la categoría A, $18,9 \%$ de la categoría B, $5,5 \%$ de la categoría C, $1,0 \%$ de la categoría D y $0,1 \%$ de la categoría X. Conclusiones: A pesar de la mayor prevalencia del uso de medicamentos durante el embarazo, la mayoría de los cuales se consideran seguros durante el embarazo. Sin embargo, es importante que el uso de medicamentos durante el embarazo sea monitoreado y guiado por profesionales de la salud para asegurar su uso racional.

Palabras clave: Preparaciones farmacéuticas; El embarazo; Epidemiología; Descriptiva; Prevalencia.

\section{Introduction}

Avoiding the use of medicines during pregnancy has been a recommended practice since thalidomide accident, used as an antiemetic in the $1960 \mathrm{~s}$, and caused an outbreak of phocomelia, a rare congenital malformation, with about 4000 occurrences, representing 498 deaths. However, during pregnancy, is necessary the use of medicines mainly by women with chronic diseases or those who suffer medical complications (Mcbride, 1961).

In cases of medicine use during pregancy the professional health care must evaluate the benefits, the recommended dose, duration of treatment and the potential risks of its use by the developing mother and baby. Because during pregnancy, important physiological changes occur in the woman's body that are directly reflected in the processes of metabolizing xenobiotics, causing metabolic, pharmacokinetic and pharmacodynamic changes, which can modify the efficacy and drug toxicity (Lynch et. al, 2018; Frederiksen, 2011).

The dynamics of the development of pregnancy makes it difficult to carry out studies related to the efficacy and toxicity of drugs during pregnancy due to ethical and technical obstacles to conducting clinical trials. Consequently, it is not possible to understand enough about the safety, efficacy and pharmacokinetic changes in pregnant women. Thus, the assessment of safety in the use of medicines by this special population usually only occurs in phase IV (pharmacoepidemiological studies), that is, during commercialization (Chan et. al, 2012; Frederiksen, 2011).

In order to promote safer pharmacotherapy and guide the prescriber in the best therapeutic choice, the drugs were classified according to their toxicity to pregnant women and fetuses. The Food and Drug Administration organized a scale of risk categories associated with the use of medications during pregnancy. These drugs are classified into five categories with 
Research, Society and Development, v. 11, n. 2, e21811224986, 2022

(CC BY 4.0) | ISSN 2525-3409 | DOI: http://dx.doi.org/10.33448/rsd-v11i2.24986

increasing degrees of risk. In Brazil, the National Health Surveillance Agency (ANVISA) (Anvisa, 2010; FDA, 2010) adopted the FDA scale to help medics in the safe prescription of medication for this population.

The use of drugs during pregnancy is unavoidable, according to a systematic review of studies published between 2013 and 2018, most women reported using at least one drug during pregnancy, and most drugs used belong to classes in that use is considered safe. However, more recent pharmacoepidemiological studies focusing on adequate safety for the correct use of medications during pregnancy are still scarce, especially in countries like Brazil. This lack of studies can generate serious errors that result in the inappropriate prescription and use of medications (Silva et. al, 2018)

In this context, the objective of this study was to describe the profile of medication use during pregnancy and classify these medications used according to the toxicity scale standardized by the FDA.

\section{Methodology}

This is a descriptive cross-sectional study with based data from the cohort entitled "Etiological factors of preterm birth and consequences of perinatal factors on child health: birth cohorts in two Brazilian cities (BRISA)", conducted by the Federal University of Maranhão in collaboration with the Faculty of Medicine of the University of São Paulo in Ribeirão Preto, in the municipalities of São Luís (Maranhão) and Ribeirão Preto (São Paulo). This study only includes data from postpartum women participating in the BRISA study who delivered in a hospital or maternity hospital in the city of São Luís, between January and December 2010.

The city of São Luís, capital of Maranhão state, is located in the northeast region of Brazil, whose estimated population in 2010 was 1,019,327 inhabitants, of which 369,889 are women of childbearing age (between 10 and 49 years old) (DATASUS, 2010).

During the study period, all hospitals and maternity hospitals, except those that performed less than 100 births per year, were visited and births (live or still) recorded by the researchers.

The minimum calculated size of the birth sample was set at 5000 participants. The mothers were selected through a stratified sampling with a quota proportional to the number of births in each hospital or maternity included in the study, randomly selecting one woman for every three births. After the draw, the mothers were identified and interviewed. In cases where the discharge took place before the interview, it was carried out at home, if the mother lived in the city.

The inclusion criteria for the study were to live in São Luís and have knowledge about the medications used during pregnancy. Knowledge about the use of medications during pregnancy was assessed for safety in the reporting of mothers.

Interviews were conducted within the first 72 hours after delivery by trained interviewers using a standardized questionnaire. Sociodemographic information, prenatal care and medication use during pregnancy were collected.

Women's age was obtained in full years and categorized as $<20$ years, 20 to 34 years and 35 years or more. Skin color was self-reported and classified as white, black, brown or other. Marital status was defined as: with a partner (considering those married or in a stable union) and without a partner (including single, separated/divorced, widowed or without a stable union). The variable performing prenatal care was categorized in a dichotomous way (yes or no).

Regarding the use of medication, mothers were asked about the use of any medication during pregnancy, not specifying the gestational moment or duration of treatment, and if so, the name of the medication was asked.

It is important to mention that measures of effects or application of statistical tests were not estimated in relation to the use of misoprostol during pregnancy and the frequency of health problems in newborns. Thus, it was not possible to infer the association between the outcomes and exposure to misoprostol during pregnancy, nor was information collected about the time the drug was used to reinforce its possible adverse effects. 
Research, Society and Development, v. 11, n. 2, e21811224986, 2022

(CC BY 4.0) | ISSN 2525-3409 | DOI: http://dx.doi.org/10.33448/rsd-v11i2.24986

The classification of drugs according to anatomical, therapeutic and chemical subgroup was performed according to the international standard of the World Health Organization (WHO) considering the Anatomical Therapeutic Chemical Classification (ATCC) (WHO/ATC/DDD Index 2021). By this classification system, active ingredients are classified into levels according to the organs and/or systems where they act and their therapeutic, pharmacological and chemical properties.

To classify the drugs as to potential risks to fetal development, the FDA criteria were used, whose classification is adopted and supervised by ANVISA in its national pharmacovigilance system. According to this classification, drugs are classified by the letters A, B, C, D and X. Drugs that belong to group A are considered safe drugs, since adequate and wellcontrolled studies have not shown risk to the fetus in the first trimester and there is no evidence of risk in the other trimesters of pregnancy. Category B includes drugs in which animal studies have not shown fetal risk, however, there are no adequate and well-controlled studies in pregnant women that can confirm their safety. Category C encompasses drugs in which studies indicate adverse effects on the fetus of animals, there are no adequate and well-controlled studies in humans and these substances should only be administered if the benefit justifies the teratogenic potential. Category D includes drugs in which there is positive evidence of fetal and human risk, however, the benefits of use in pregnant women may be acceptable depending on the use situation, in the judgment of the clinician. Category $\mathrm{X}$ includes medicines in which studies in animals or humans reveal harmful effects on the fetus, which outweigh their benefits and, therefore, should not be used during pregnancy. Medicines made up of associations of more than a drug were considered to be in the highest risk class presented by its components ( Puffer et. al, 1987).

To describe the health conditions of newborns exposed to category X drugs during pregnancy, the following variables were considered: birth condition (alive or dead), health problem (presence or absence), type of health problem, defect congenital (presence or absence) and birth weight. Birth weight was classified considering the criteria recommended by the World Health Organization10: underweight $(<2500 \mathrm{~g})$, insufficient weight $(2500 \mathrm{~g}$ to $2999 \mathrm{~g})$, adequate weight $(3000 \mathrm{~g}$ to $3999 \mathrm{~g})$ and overweight $(\geq 4000 \mathrm{~g})$.

Statistical analyzes were performed using Stata software version 14.0. A descriptive analysis of the data was performed, with the variables presented as absolute and relative frequencies.

The BRISA Study was approved by the Research Ethics Committee of the University Hospital of UFMA (Opinion No. 223/2009), according to the guidelines of the National Research Ethics Commission (CONEP), respecting the ethical standards established in the 1975 Declaration of Helsinki, revised in 2000. Written informed consent was obtained from research participants.

\section{Results}

In this study 5,110 postpartum women were interviewed. Most of them were between 20 and 34 years of age ( $73.7 \%$ ), self-declared of brown skin color (67.5\%) and lived with a partner (80.8\%). Among those interviewed, 98.0\% underwent prenatal care.

The prevalence of use of at least one medication during pregnancy was $93.5 \%$, with a total of 10,951 medications used. Among the medicine used, 296 items could not be described as the women did not remember the name of the medicine. Thus, a total of 10,655 drugs were evaluated and classified in this study.

In order to determine the frequency of medications used during pregnancy, we used ATCC system code with therapeutic subgroup, chemical substance and ATCC codes (Table 1). The most used drugs were from the therapeutic subgroup of antianemic preparations. Within this subgroup, the most used chemical substances were ferrous sulfate (72.2\%), iron and multivitamins $(4.9 \%)$, followed by folic acid (62.9\%) and associations with folic acid (6.7\%). The therapeutic 
Research, Society and Development, v. 11, n. 2, e21811224986, 2022

subgroup of vitamins, especially chemical substances related to multivitamins and other minerals (30.3\%) were also widely used during pregnancy.

Other medicines, such as those belonging to therapeutic subgroups of analgesics, antibacterials for systemic use, antiemetics/antinauseants and antihypertensives, are also remarkable for their frequency of use during pregnancy. In the analgesic subgroup, paracetamol (12.3\%) was the drug most used by women during pregnancy.

Antibacterials for systemic use presented a wide variety of drugs, however, cephalexin (5.6\%) was the most commonly used chemical substance. Antiemetics/antinauseants and antihypertensives were basically represented by scopolamine butylbromide and methyldopa, which were used by $5.4 \%$ and $3.6 \%$ of the women in the study, respectively (Table 1).

Regarding anatomical classification, the drugs most used during pregnancy were related to blood and blood-forming organs $(65,8 \%)$, followed by the alimentary tract and metabolism $(14,5 \%)$ subgroup (Figure 1).

According to the FDA risk categories, Table 2 presents the classification of drugs used during pregnancy. Among the medicines used, $74.5 \%$ belonged to category A, $18.9 \%$ to category $\mathrm{B}, 5.5 \%$ to category $\mathrm{C}, 1.0 \%$ to category $\mathrm{D}$ and $0.1 \%$ to category X. In category D, there are reports of use of calcium carbonate, calcium carbonate associated with other substances and progesterone. In category $\mathrm{X}$, the use of misoprostol was reported. This drug was used by pregnant women before delivery, or hospitalization, thus characterizing its use prohibited, as the use of the substance misoprostol is restricted to hospital establishments duly registered and accredited by Anvisa (Table 2).

Based in the toxicity level according FDA classification, Table 3 shows the clinical characteristics of newborns exposed to category $\mathrm{X}$ drug. All newborns exposed to misoprostol drug were born alive and none had a congenital defect. However, $26.7 \%$ had one or more health problems, such as prematurity, transient tachypnea/respiratory discomfort, dyspnea and moaning. As for birth weight, $20.0 \%$ were born with low weight and $6.7 \%$ with excess weight (Table 3 ). 
Research, Society and Development, v. 11, n. 2, e21811224986, 2022

(CC BY 4.0) | ISSN 2525-3409 | DOI: http://dx.doi.org/10.33448/rsd-v11i2.24986

Table 1. Frequency of medicines used during pregnancy according to therapeutic subgroup and chemical substance. São Luís, Maranhão, Brazil, 2010.

\begin{tabular}{|c|c|c|c|c|}
\hline Therapeutic Subgrup & Drug & ATCC code & $\mathbf{N}$ & $\%$ \\
\hline \multirow{2}{*}{ Analgesics } & metamizole sodium & N02BB02 & 75 & 1.6 \\
\hline & paracetamol & N02BE01 & 588 & 12.3 \\
\hline $\begin{array}{c}\text { Antiinflammatory and antirheumatic } \\
\text { products }\end{array}$ & diclofenac & M01AB05 & 25 & 0.5 \\
\hline \multirow{7}{*}{ Antibacterials for systemic use } & ampicillin & J01CA01 & 35 & 0.7 \\
\hline & amoxicillin & J01CA04 & 71 & 1.5 \\
\hline & benzathine benzylpenicillin & J01CE08 & 16 & 0.3 \\
\hline & cefalexin & J01DB01 & 269 & 5.6 \\
\hline & $\begin{array}{l}\text { sulfamethoxazole and } \\
\text { trimethoprim }\end{array}$ & J01EE01 & 6 & 0.1 \\
\hline & spiramycin & J01FA02 & 12 & 0.3 \\
\hline & metronidazole & J01XD01 & 48 & 1.0 \\
\hline Gynecological antiinfectives and antiseptics & nystatin & G01AA01 & 99 & 2.1 \\
\hline \multirow{3}{*}{ Vitamins } & $\begin{array}{l}\text { multivitamins and other } \\
\text { minerals }\end{array}$ & A11AA03 & 1.446 & 30.3 \\
\hline & ascorbic acid (vit C) & A11GA01 & 15 & 0.3 \\
\hline & $\begin{array}{l}\text { ascorbic acid (vitamin } \mathrm{C}) \\
\text { combinations* }\end{array}$ & A11GB & 30 & 0.6 \\
\hline \multirow[b]{2}{*}{ Mineral Supplements } & calcium carbonate & A12AA04 & 32 & 0.7 \\
\hline & $\begin{array}{l}\text { calcium, combinations with } \\
\text { vitamin D and/or other drugs* }\end{array}$ & A12X & 18 & 0.4 \\
\hline Antihypertensives & methyldopa (racemic) & $\mathrm{C} 02 \mathrm{AB} 02$ & 174 & 3.6 \\
\hline Drugs for obstructive airway diseases & betamethasone & R03BA04 & 17 & 0.4 \\
\hline Thyroid therapy & levothyroxine sodium & H03AA01 & 16 & 0.3 \\
\hline $\begin{array}{l}\text { Sex hormones and modulators of genital } \\
\text { system }\end{array}$ & progesterone & G03DA04 & 54 & 1.1 \\
\hline Peripheral vasodilators & isoxsuprine & C04AA01 & 64 & 1.3 \\
\hline \multirow{4}{*}{ Antianemic preparations } & ferrous sulfate & B03AA07 & 3.449 & 72.2 \\
\hline & iron and multivitamins* & B03AE03 & 234 & 4.9 \\
\hline & folic acid & B03BB01 & 3.007 & 62.9 \\
\hline & folic acid, combinations* & B03BB51 & 318 & 6.7 \\
\hline Other Gynecologicals & misoprostol & G02AD06 & 15 & 0.3 \\
\hline \multirow{3}{*}{ Drugs for acid related disorders } & omeprazole & $\mathrm{A} 02 \mathrm{BC} 01$ & 13 & 0.3 \\
\hline & aluminium hydroxide & $\mathrm{A} 02 \mathrm{AB} 01$ & 34 & 0.7 \\
\hline & magnesium hydroxide & A02AA04 & 12 & 0.3 \\
\hline \multirow{2}{*}{ Anti-histamínicos e uso sistêmico } & diphenhydramine (dramin) & R06AA02 & 161 & 3.4 \\
\hline & meclozine & R06AE05 & 22 & 0.5 \\
\hline Antiemetics and antinauseants & scopolamine & A04AD01 & 258 & 5.4 \\
\hline $\begin{array}{c}\text { Drugs for functional gastrointestinal } \\
\text { disorders }\end{array}$ & dimethicone (silicones) & $\mathrm{A} 03 \mathrm{AX} 13$ & 22 & 0.5 \\
\hline
\end{tabular}

ATCC $=$ Anatomical Therapeutic Chemical Classification System. ${ }^{\text {a }}$ Proportion of each chemical substance use among the total number of women who reported using at least one drug during pregnancy $(n=4,778)$. *In association with other substances. Fonte: Autores (2022). 
Research, Society and Development, v. 11, n. 2, e21811224986, 2022

(CC BY 4.0) | ISSN 2525-3409 | DOI: http://dx.doi.org/10.33448/rsd-v11i2.24986

Figure 1. Medicines used during pregnancy according to the main anatomical subgroup in the ATC code.

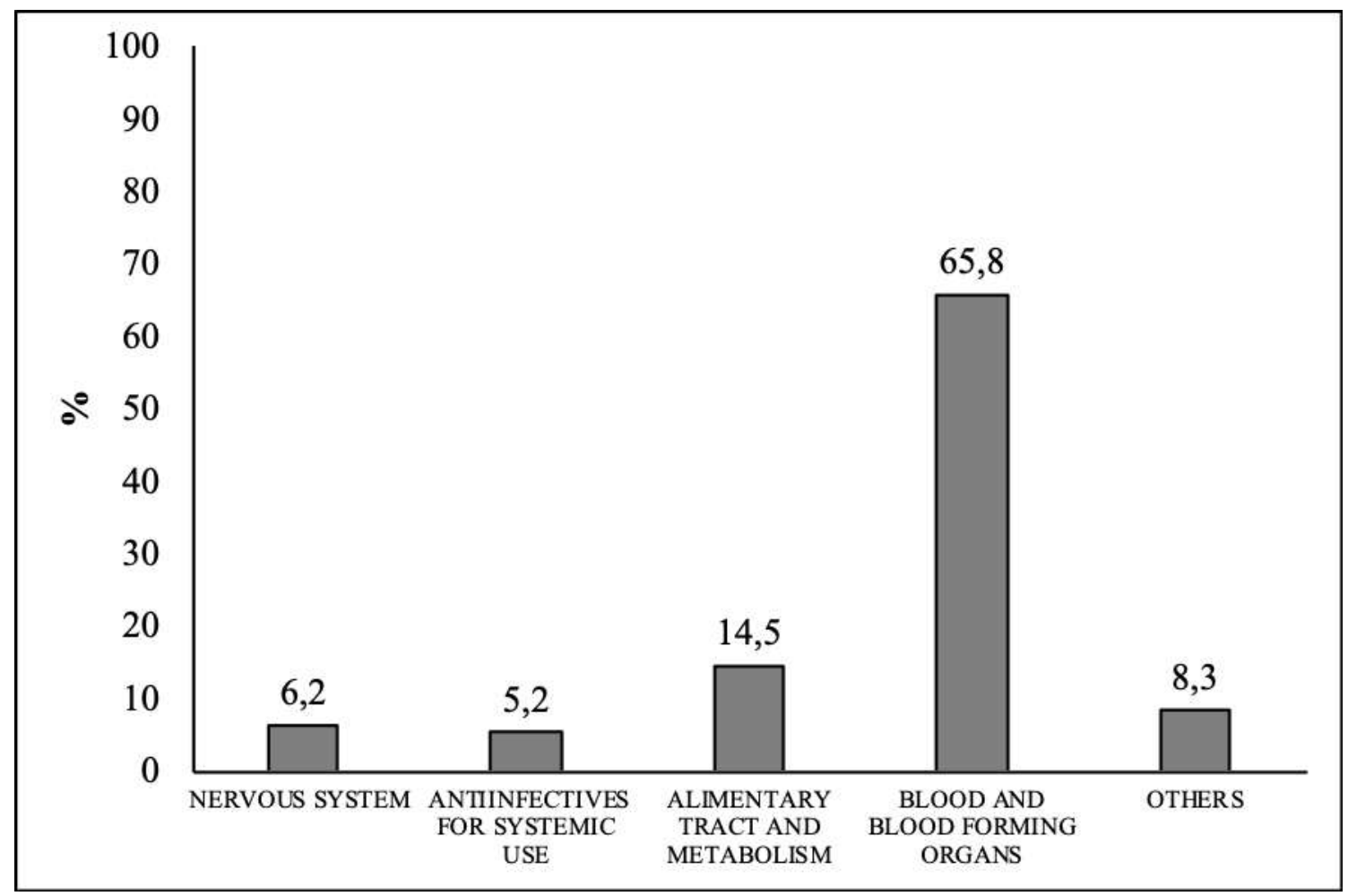

Fonte: Autores (2022). 
Research, Society and Development, v. 11, n. 2, e21811224986, 2022

(CC BY 4.0) | ISSN 2525-3409 | DOI: http://dx.doi.org/10.33448/rsd-v11i2.24986

Table 2. Frequency of medicines used during pregnancy according to Food and Drug Administration (FDA) categories. São Luís, Maranhão, Brazil, 2010.

\begin{tabular}{|c|c|c|c|}
\hline FDA Category & Drug & $\mathbf{N}$ & $\%$ a \\
\hline \multirow{5}{*}{ A } & Ferrous sulfate & 3.449 & 32.4 \\
\hline & Folic acid ** & 3.007 & 28.2 \\
\hline & Levothyroxine sodium & 16 & 0.2 \\
\hline & Magnesium hydroxide & 12 & 0.1 \\
\hline & Multivitamins and other minerals & 1.446 & 13.6 \\
\hline \multirow{11}{*}{ B } & Amoxicillin & 71 & 0.7 \\
\hline & Benzathine benzylpenicillin & 16 & 0.2 \\
\hline & Cefalexin & 269 & 2.5 \\
\hline & Dimethicone (silicones) & 22 & 0.2 \\
\hline & Diphenhydramine & 161 & 1.5 \\
\hline & Folic acid** & 318 & 3.0 \\
\hline & Iron\# & 234 & 2.2 \\
\hline & Meclozine & 22 & 0.2 \\
\hline & Metronidazole & 48 & 0.5 \\
\hline & Paracetamol & 588 & 5.5 \\
\hline & Scopolamine & 258 & 2.4 \\
\hline \multirow{13}{*}{$\mathrm{C}$} & Ascorbic acid (vit C) & 15 & 0.1 \\
\hline & Ascorbic acid (vit C) combinations & 30 & 0.3 \\
\hline & Aluminium hydroxide & 34 & 0.3 \\
\hline & Ampicillin & 35 & 0.3 \\
\hline & Betamethasone & 17 & 0.2 \\
\hline & Diclofenac & 25 & 0.2 \\
\hline & Isoxsuprine & 64 & 0.6 \\
\hline & Metamizole sodium & 75 & 0.7 \\
\hline & Methyldopa & 174 & 1.6 \\
\hline & Nystatin & 99 & 0.9 \\
\hline & Omeprazole & 13 & 0.1 \\
\hline & Spiramycin & 12 & 0.1 \\
\hline & Sulfamethoxazole and trimethoprim & 6 & 0.1 \\
\hline \multirow{3}{*}{$\mathrm{D}$} & Calcium carbonate & 32 & 0.3 \\
\hline & Calcium carbonate\# & 18 & 0.2 \\
\hline & Progesterone & 54 & 0.5 \\
\hline $\mathrm{X}$ & Misoprostol & 15 & 0.1 \\
\hline
\end{tabular}

**Dose dependent classification; \#In association with other substances. aFDA Pregnancy Category Proportion of each drug used among the total drugs used in pregnancy reported by participants $(n=10,655)$. Fonte: Autores $(2022)$. 
Table 3. Clinics characteristics of newborns exposed to drug classified in category X by Food and Drug Administration (FDA) pregnancy categories. São Luís, Maranhão, Brazil, 2010.

\begin{tabular}{|c|c|c|c|}
\hline \multicolumn{2}{|c|}{ Newborns Characteristics } & \multicolumn{2}{|c|}{ Drug in FDA category $X$} \\
\hline & & $\mathrm{N}$ & $\%$ \\
\hline \multirow{2}{*}{ Birth condition } & Live & 15 & 100 \\
\hline & Dead & 0 & 0 \\
\hline \multirow{2}{*}{ Health problems } & Presence & 4 & 26,7 \\
\hline & Absence & 11 & 73,3 \\
\hline \multirow{4}{*}{ Type of health problem } & Prematurity & 2 & 33,3 \\
\hline & $\begin{array}{c}\text { Transient } \\
\text { tachypnea/respiratory } \\
\text { distress } \\
\end{array}$ & 2 & 33,3 \\
\hline & Dyspnea & 1 & 16,7 \\
\hline & Groaning & 1 & 16,7 \\
\hline \multirow{2}{*}{ Congenital defects } & Presence & 0 & 0,0 \\
\hline & Absence & 15 & 100,0 \\
\hline \multirow{4}{*}{ Birth weight } & $<2500 \mathrm{~g}$ & 3 & 20,0 \\
\hline & 2500 to $2999 \mathrm{~g}$ & 6 & 40,0 \\
\hline & 3000 to $3999 \mathrm{~g}$ & 5 & 33,3 \\
\hline & $\geq 4000 \mathrm{~g}$ & 1 & 6,7 \\
\hline
\end{tabular}

Fonte: Autores (2022).

\section{Discussion}

In the present study, the vast majority of women reported using at least one medicine during pregnancy. Among women who reported the use of any medication during pregnancy, the most used were anti-anemic drugs, vitamins, analgesics, antibacterials for systemic use, anti-emetics/anti-nausea and anti-hypertensives. Regarding the classification according to anatomical groups, the most used were related to blood, hematopoietic organs and the alimentary tract and metabolism. As for drug safety, most were classified within FDA risk categories A and B, however, the use of drugs that can cause fetal harm has also been reported by some women.

Our results were confirmed with literature data, because in Brazil and in other countries around the world, it was observed that women are frequently exposed to medications during pregnancy, although that other studies, report a range of diverse prevalence in medicine use during pregnancy, with frequencies ranging from $11.7 \%$ to $90.0 \%$. The Brazilian study carried out by Fontoura et al. with 699 pregnant women from Ribeirão Preto - SP, observed a prevalence of $98.0 \%$ of use of at least one medication during pregnancy. Data from the Slone Epidemiology Center Birth Defects Study showed that $93.9 \%$ of women used at least one drug during pregnancy in the United States in 2008 (Melo el al, 2009; Brum et al, 2011; Fontoura et. al, 2014; Costa et. al, 2017; Mitchel et. al, 2011; Bérard et. al, 2019; Zhang et. al, 2019). 
Research, Society and Development, v. 11, n. 2, e21811224986, 2022

(CC BY 4.0) | ISSN 2525-3409 | DOI: http://dx.doi.org/10.33448/rsd-v11i2.24986

Although the risks associated with the use of medications during pregnancy are poorly understood, the practice has proven to be interventionist, either because of the excess of medical prescription or the practice of self-medication among pregnant women (Brum et al, 2011).

Few studies classify drugs used during pregnancy according to The Anatomical Therapeutic Chemical Classification System (ATC code). Among the most recent studies that used this classification, similarly to the present study, Costa et al. and Zhang et al. also reported that the most used drugs were related to anatomical subgroups of the blood systems/hematopoietic organs and the alimentary tract and metabolism (Costa et. al, 2017; Zhang et. al, 2019)

Among the medications most used during pregnancy by the women evaluated in this study, antianemics and vitamins were the most mentioned therapeutic subgroups, following the daily supplementation of iron and folic acid in pregnant women recommended by the World Health Organization (WHO) as part of care prenatal care, with the objective of reducing the risk of low birth weight, maternal anemia and iron deficiency. Therefore, the high frequency of use of these drugs is motivated by the fact that their recommendation during pregnancy is a routine clinical intervention. However, despite the high frequency of use, it was believed that the use of anti-anemic drugs among pregnant women was greater, as it is the WHO recommendation that these supplements be used during pregnancy (Melo et al, 2009; Fontoura et. al, 2014; Costa et. al, 2017; Bérard et. al, 2019; Zhang et. al, 2019; OMS, 2013).

WHO also highlights that, in addition to iron and folic acid, supplements can be formulated to include other vitamins and minerals in accordance with the United Nations Multiple Micronutrient Preparation instructions for correcting other possible micronutrient deficiencies of the pregnant woman (OMS, 2013).

Iron, folic acid and multivitamin salts belong to risk category A of the FDA, that is, they are drugs whose use in adequate doses is considered safe during pregnancy (FDA, 2010).

Currently, the World Health Organization recommends a daily dose of 30-60 mg of elemental iron and 0.4 mg of folic acid throughout pregnancy, which should be started as soon as possible. However, the Brazilian Ministry of Health recommends that supplementation with folic acid should be started at least 30 days before the date you plan to become pregnant, aiming to prevent neural tube defects, and should be continued throughout pregnancy for prevention of maternal anemia (OMS, 2013; Brasil, 2013).

The use of analgesics was also frequently in this study, which has been reported by other studies in the literature. Within the therapeutic subgroup of analgesics, the chemical substances used and reported by women were paracetamol and sodium metamizole. The first being in the FDA risk B category, and the last in C category, suggesting a certain degree of risk in the indiscriminate use of these drugs (Melo et al, 2009; Brum et al, 2011; Fontoura et. al, 2014; Costa et. al, 2017; Bérard et. al, 2019).

Regarding paracetamol, in children, its indiscriminate use may be associated with the development of asthma, autism spectrum disorder, neurological problems, attention deficit hyperactivity disorder, behavioral changes, changes in ovarian development during intrauterine life, diseases allergies, among other adverse effects on the child's health. In pregnant women, the abusive use of paracetamol can increase the development of pre-eclampsia, deep vein thrombosis and pulmonary thromboembolism. However, as studies are inconclusive and there is great experience in the use of the drug during pregnancy, paracetamol remains the analgesic of choice during pregnancy, but the lowest dose and for the shortest time possible should be used (Rebordosa et. al, 2010; Toda, 2017).

Although it has been suggested that exposure to metamizole sodium (dipyrone) during pregnancy does not increase the risk of congenital anomalies and other adverse events. Dipyrone is still a stigmatized drug in several contexts due to reports 
Research, Society and Development, v. 11, n. 2, e21811224986, 2022

(CC BY 4.0) | ISSN 2525-3409 | DOI: http://dx.doi.org/10.33448/rsd-v11i2.24986

of its relationship with agranulocytosis and aplastic anemia. This reinforces the need for future investigations to determine the teratogenic effects of this drug and identify other adverse perinatal events (Dal Pizzol et. al, 2009).'

Regarding the use of systemic antibacterials, this and other Brazilian studies reported a considerable frequency of consumption among pregnant women. These data show us the importance of pharmacological surveillance, since the drugs reported belong to FDA risk categories $\mathrm{B}$ and $\mathrm{C}$. Cephalexin was the most used antibiotic, and according to Vidal $e t$ al., the use of antibiotics during pregnancy can increase the risk of low birth weight and alterations in the fetal microbiota (Melo et al, 2009; Fontoura et. al, 2014; Vidal et. al, 2013)

The use of antiemetic and antinauseant drugs, more specifically scopolamine butylbromide, was also among the most used drugs during pregnancy in the present study, and a similar finding was verified by Fontoura et al..The frequent use of this drug during pregnancy may be related to the occurrence of nausea and vomiting in pregnant women, especially in the first trimester. Scopolamine butylbromide is classified in FDA risk category B, it should not be used by pregnant women without medical advice (FDA, 2010; Fontoura et. al, 2014).

The use of the antihypertensive drug methyldopa, a drug to control blood pressure, was reported by 174 women in the study. However, among the study participants, only 107 pregnant women reported a diagnosis of arterial hypertension during prenatal consultations (Data not shown in table). It is believed that this difference may be the result of information bias in reporting the diagnosis of arterial hypertension by women diagnosed as hypertensive before pregnancy and who continued using the drug during pregnancy. Methyldopa is classified in FDA risk category $\mathrm{C}$ and should be used rationally. Although no evidence of increased risk of birth defects has been reported, there may be a significantly increased risk of preterm birth in pregnancies of women treated with methyldopa. Thus, further studies are needed to confirm the safe use of this drug during pregnancy and to clarify its effects on birth conditions and perinatal outcomes (Hoeltzenbein et. al, 2017).

Although with low frequency, some women in the present study reported the use of misoprostol $(0.1 \%)$, classified within the FDA risk category $\mathrm{X}$ and whose marketing has been banned due to its teratogenic effect. Other authors have reported higher frequencies of use of this drug during pregnancy. In the study by Dal Pizzol et al., with women from six Brazilian capitals, the frequency of misoprostol use during pregnancy was 5.0\%, while Zhang et al. reported that, in 2015 , 0.9 $\%$ of pregnant women in China used this drug during pregnancy. However, due to the limitations of the studies, such frequencies can be even higher. The possible underestimation of the frequency of misoprostol use during pregnancy may be related to the fact that its use by pregnant women is associated with the desire for abortion, resulting in the omission of the use of this drug by some women during the interview in the study (Zhang et. al, 2019; Dal Pizzol et. al, 2008).

In Brazil, the sale of misoprostol to the general public has been prohibited since 1998, and its use is restricted to the hospital network. Thus, its acquisition outside hospitals is only possible clandestinely, especially as an alternative to interrupt unwanted pregnancies, due to its abortive effect. Studies evaluating the effects of exposure to misoprostol during pregnancy have indicated an increased risk of fetal malformations and major congenital anomalies (Diniz \& Castro, 2011; Barbero et. al, 2011; Vauzelle et. al, 2013).

In the present study, the health problems presented by newborns exposed to misoprostol during pregnancy were prematurity, transient tachypnea/respiratory discomfort, dyspnea and moaning. Prematurity related to the use of misoprostol during pregnancy is well documented in the literature. However, no relationship between transient tachypnea/respiratory discomfort, dyspnea, whining in newborns with the use of misoprostol during pregnancy has been reported in the literature (Abraham et. al, 2014; Escumalha et. al, 2005).

As a limitation of the study, we have the possibility of memory bias, since the mothers were asked about the use of medications during pregnancy, and many of them could not remember medications used during the entire period of pregnancy. 
Research, Society and Development, v. 11, n. 2, e21811224986, 2022

(CC BY 4.0) | ISSN 2525-3409 | DOI: http://dx.doi.org/10.33448/rsd-v11i2.24986

In addition, because the use of prohibited drugs during pregnancy is socially disapproved, the report of their use by some women may have been omitted. Thus, we cannot rule out the possibility that the frequencies of drug use during pregnancy reported in the study are underestimated.

On the other hand, as a strength of the study, the evaluation of a large sample of participants stands out, which was representative of the population of women who underwent hospital births in the city of São Luís during the period of the research.

\section{Final Considerations}

The results of the present study show a high prevalence of drug use during pregnancy and that although most of these are safe to use during pregnancy, the use of different drugs should be monitored and guided by health professionals, in order to ensure the its rational use.

Carrying out similar epidemiological studies are essential to trace and compare the profile of drug use during pregnancy in different parts of the country. Greater knowledge about this profile provides changes in the formulation of programs and public policies aimed at pregnant women, which are still so incipient in Brazil.

\section{Acknowledgments}

We thank the interviewers and the mothers who kindly agreed to participate in the study. This manuscript was carried out with the support of the Coordenação de Aperfeiçoamento de Pessoal de Nível Superior - Brazil (CAPES) - Financing Code 001. The study also received financial support from the Conselho Nacional de Desenvolvimento Científico e Tecnológico (CNPq - Process No.: 47923/ 2011-7), Fundação de Amparo à Pesquisa e Desenvolvimento Científico do Maranhão (FAPEMA - PRONEX No.: 00035/2008) and Fundação de Amparo à Pesquisa do Estado de São Paulo (FAPESP - Process No.: 2008/53593-0).

\section{References}

Abraham, C., Meirowitz, N., \& Kohn, N. (2014). Labor induction for premature rupture of membranes using vaginal misoprostol versus dinoprostone vaginal insert. Am J Perinatol. 3: 181-6.

Agência Nacional de Vigilância Sanitária. Resolução da Diretoria Colegiada - RDC n 17 , de 16 de abril de 2010, dispõe sobre Boas Práticas de fabricação de Medicamentos. Diário Oficial da União, Poder Executivo, Brasília, DF, 17 de abril de 2010. http://bvsms.saude.gov.br/bvs/saudelegis/anvisa/2010/res0060_17_12_2010.html

Barbero, P., Liascovich, R., Valdez, R., \& Moresco, A. (2011). Misoprostol teratogenicity: a prospective study in Argentina. Arch Argent Pediatr. 109: 22631.

Bérard, A., Abbas-Chorfa, F., Kassai, B., Vial, T., Nguyen, K. A., Sheehy, O., \& Schott, A. M. (2019). The French Pregnancy Cohort: Medication use during pregnancy in the French population. PloS one. 14: e0219095.

Brasil. Programa Nacional de Suplementação de Ferro: Manual de condutas gerais. Brasília: Ministério da Saúde, 2013.24 p. [acesso em 12 mar 2021]. http://bvsms.saude.gov.br/bvs/publicacoes/manual_suplementacao_ferro_condutas_gerais.pdf

Brum, L. F. D. S., Pereira, P., Felicetti, L. L., \& Silveira, R. D. D. (2011) Utilização de medicamentos por gestantes usuárias do Sistema Único de Saúde no município de Santa Rosa (RS, Brasil). Cien Saude Colet. 16: 2435-42.

Chan, M., Wong, I. C. K., \& Sutcliffe, A. G. (2012) Prescription drug use in pregnancy: more evidence of safety is needed. TOG. 2: 87-92.

Costa, D. B., Coelho, H. L. L., \& Santos, D. B. D. (2017) Utilização de medicamentos antes e durante a gestação: prevalência e fatores associados. Cad Saude Publica. 33: e00126215.

Dal Pizzol, T. S., Sanseverino, M. T. V., \& Mengue, S. S. (2008) Exposure to misoprostol and hormones during pregnancy and risk of congenital anomalies Cad Saude Publica. 24: 1447-53

Dal Pizzol, T. S., Schüler-Faccini, L., Mengue, S. S., \& Fischer, M. I. (2009) Dipyrone use during pregnancy and adverse perinatal events. Arch Gynecol Obstet. 279: 293-7. 
Research, Society and Development, v. 11, n. 2, e21811224986, 2022 (CC BY 4.0) | ISSN 2525-3409 | DOI: http://dx.doi.org/10.33448/rsd-v11i2.24986

Datasus. População residente - Estudo de estimativas populacionais por município, idade e sexo $2000-2015$ - Brasil. 2010. http://tabnet.datasus.gov.br/cgi/deftohtm.exe?novapop/cnv/popbr.def

Diniz, D., \& Castro, R. (2011) O comércio de medicamentos de gênero na mídia impressa brasileira. Cad Saude Publica. 27: 94-102.

Escumalha, M., Gouveia, C., Cunha, M., Vale, F., \& Machado, M. C. (2005) Neonatal morbidity and outcome of live born premature babies after attempted illegal abortion with misoprostol. Pediatr Nurs. 31: 228-31.

Fontoura, A., Ayres, L. R., Martins-Nagai, M., Dewulf, N. L., Santos, V., Martinez, E. Z., \& Pereira, L. R. (2014) Prevalence of medication use among low risk pregnant women: a drug utilization study. Afr J Pharm Pharmacol 8:883-92.

Food and Drug Administration. Highlights of Prescribing Information. 2010. https://www.fda.gov/media/96632/download

Frederiksen, M. C. (2011) The new FDA pregnancy labeling requirements for drugs. J Midwifery Womens Health. 56: 303-7.

Hoeltzenbein, M., Beck, E., Fietz, A. K., Wernicke, J., Zinke, S., Kayser, A., Padberg, S., Weber-Schoendorfer, C., Meister, R., \& Schaefer, C. (2017) Pregnancy Outcome After First Trimester Use of Methyldopa: A Prospective Cohort Study. Hypertension. 70: 201-8.

Lynch, M. M., Squiers, L. B., Kosa, K. M., Dolina, S., Read, J. G., Broussard, C. S., Frey, M. T., Polen, K. N., Lind, J. N., Gilboa, S. M., \& Biermann, J. (2018) Making decisions about medication use during pregnancy: Implications for communication strategies. Matern Child Health J. 22:92-100.

Mcbride, W. G. (1961) Thalidomide and congenital malformations. Lancet. 1358: 90927-8.

Melo, S. C. C. S., Pelloso, S. M., Carvalho, M. D. B., \& Oliveira, N. L. B. (2009) Uso de medicamentos por gestantes usuárias do Sistema único de Saúde. Acta Paul Enferm 22: 66-70.

Mitchell, A. A., Gilboa, S. M., Werler, M. M., Kelley, K. E., Louik, C., \& Hernandez-Diaz, S. (2011) National Birth Defects Prevention Study. Medication use during pregnancy, with particular focus on prescription drugs: 1976-2008. Am J Obstet Gynecol. 205: e1-e8.

Organização Mundial de Saúde. Diretriz: Suplementação diária de ferro e ácido fólico em gestantes. Genebra: Organização Mundial da Saúde; 2013. http://189.28.128.100/dab/docs/portaldab/documentos/guia_gestantes.pdf

Puffer, R. R., \& Serrano, C. (1987) Patterns of birth weight. Washington (DC): PAHO; (Scientific Publication, 504).

Rebordosa, C., Zelop, C. M., Kogevinas, M., Sørensen, H. T., \& Olsen, J. (2010) Use of acetaminophen during pregnancy and risk of preeclampsia, hypertensive and vascular disorders: a birth cohort study. J Matern Fetal Neonatal Med. 23: 371-8.

Silva, A. S. D., Maciel, G. D. A., Wanderley, L. S. D. L., \& Wanderley, A. G. (2018) Indicadores do uso de medicamentos na atenção primária de saúde: uma revisão sistemática. Rev Panam Salud Publica. 2018; 41: e132.

Toda, K. (2017) Is acetaminophen safe in pregnancy? Scand J Pain 17: 445-6.

Vauzelle, C., Beghin, D., Cournot, M. P., \& Elefant, E. (2013) Birth defects after exposure to misoprostol in the first trimester of pregnancy: prospective follow-up study. Reprod Toxicol. 36: 98-103.

Vidal, A. C., Murphy, S. K., Murtha, A. P., Schildkraut, J. M., Soubry, A., Huang, Z., Neelon, S. E. B., Fuemmeler, B., Iversen, E., Wang, F., Kurtzberg, J., Jirtle, R. L., \& Hoyo, C. (2013) Associations between antibiotic exposure during pregnancy, birth weight and aberrant methylation at imprinted genes among offspring. Int J Obes. 37: 907-13.

World Health Organization. ATC/DDD Index 2021. Collaborating Centre for Drug Statistics Methodology: Oslo, Norway. https://www.whocc.no/atc_ddd_index/

Zhang, J., Ung, C. O. L., Wagner, A. K., Guan, X., \& Shi, L. (2019) Medication use during pregnancy in Mainland China: a cross-sectional analysis of a national health insurance database. Clin Epidemiol. 11: 1057. 